\title{
Author Correction: Correlating advanced microscopies reveals atomic-scale mechanisms limiting lithium-ion battery lifetime
}

\author{
Baptiste Gault (1) \& Jonathan D. Poplawsky (1)
}

Correction to: Nature Communications https://doi.org/10.1038/s41467-021-24121-9, published online 18 June 2021.

The original version of this Article omitted a reference to previous work in "Chae, B. G. et al. Evolution and expansion of Li concentration gradient during charge-discharge cycling. Nat Commun 12, 3814 (2021)". This has been added as reference [14] at "Chae et al. combined... [14]". This has been corrected in the PDF and HTML versions of the Article.

Published online: 08 July 2021

\begin{abstract}
(c) Open Access This article is licensed under a Creative Commons Attribution 4.0 International License, which permits use, sharing, adaptation, distribution and reproduction in any medium or format, as long as you give appropriate credit to the original author(s) and the source, provide a link to the Creative Commons license, and indicate if changes were made. The images or other third party material in this article are included in the article's Creative Commons license, unless indicated otherwise in a credit line to the material. If material is not included in the article's Creative Commons license and your intended use is not permitted by statutory regulation or exceeds the permitted use, you will need to obtain permission directly from the copyright holder. To view a copy of this license, visit http://creativecommons.org/licenses/by/4.0/.
\end{abstract}

(C) The Author(s) 2021 